Artikel Penelitian

\title{
Hubungan Konsumsi Zat Besi dengan Kejadian Anemia pada Murid SMP Negeri 27 Padang
}

\author{
Istiya Putri Lestari ${ }^{1}$, Nur Indrawati Lipoeto ${ }^{2}$, Almurdi $^{3}$
}

\begin{abstract}
Abstrak
Anemia merupakan salah satu masalah kesehatan utama masyarakat di negara berkembang. Di Indonesia, penyebab utama terjadinya anemia adalah kekurangan zat besi. Besi merupakan zat gizi mikro yang dibutuhkan tubuh untuk membentuk hemoglobin. Anemia defisiensi besi sering terjadi pada remaja dan dapat mengenai semua kelompok terutama yang memiliki sosial ekonomi rendah. Tujuan penelitian ini adalah menentukan hubungan konsumsi zat besi dengan kejadian anemia pada murid SMP Negeri 27 Padang. Penelitian ini menggunakan desain potong lintang dari bulan Februari - Juli 2015. Jumlah sampel adalah 102 murid yang dipilih secara systematic random sampling. Konsumsi zat besi diukur dengan kuisioner food recall $2 \times 24$ jam dan penetapan kadar hemoglobin dengan metode hemometer digital. Analisis statistik yang digunakan uji korelasi Pearson. Hasil studi menunjukkan kekuatan hubungan yang sangat lemah. Berpola positif, artinya semakin tinggi konsumsi zat besi semakin tinggi kadar hemoglobinnya. Tidak terdapat hubungan yang bermakna antara konsumsi zat besi dengan kejadian anemia pada murid SMP Negeri 27 Padang.
\end{abstract}

Kata kunci: zat besi, anemia, kadar hemoglobin

\begin{abstract}
Anemia is one of the major public health problems in developing countries. In Indonesia, the main cause of anemia is iron deficiency. Iron is a micronutrient that the body needs to make hemoglobin. Iron deficiency anemia is more common in adolescents and may involve all groups, especially with a low socioeconomic. The objective of this study was to determine the correlation between the consumption of iron and the incident of anemia on students of SMP Negeri 27 Padang. This research used cross sectional design with 102 samples at SMP Negeri 27 Padang in February - July 2015. Samples were selected by systematic random sampling. Iron consumption measured by questionnaires food recall $2 \times 24$ hours and hemoglobin levels with digital haemometer method. Statistical analysis used the Pearson correlation test. The conclusion is no correlation between the consumption of iron and the incident of anemia on students of SMP Negeri 27 Padang.
\end{abstract}

Keywords: iron, anemia, hemoglobin levels

Affiliasi penulis: 1. Prodi Profesi Dokter Fakultas Kedokteran Universitas Andalas Padang (FK Unand), 2. Bagian Gizi FK Unand, 3. Bagian Patologi Klinik FK Unand/RSUP Dr. M. Djamil Padang Korespondensi: Istiya Putri Lestari, Email: istiyaputri@gmail.com, Telp: 085382111995

\section{PENDAHULUAN}

Anemia merupakan masalah medis dan masalah kesehatan utama masyarakat yang sering dijumpai di seluruh dunia, terutama di negara berkembang seperti Indonesia. Kelainan ini adalah merupakan penyebab debilitas kronik yang mempunyai dampak besar terhadap kesehatan, ekonomi dan kesejahteraan sosial. Diperkirakan lebih dari $30 \%$ penduduk dunia atau 1,5 miliar orang menderita anemia dengan sebagian besar diantaranya tinggal di daerah tropis. ${ }^{1}$ Prevalensi anemia secara global sekitar 51\%. ${ }^{2}$ Menurut Departemen Kesehatan tahun 2014, prevalensi anemia pada remaja dan usia produktif sebesar $17-18 \%{ }^{3}$ 
Anemia merupakan penurunan kadar hemoglobin, hitung eritrosit, dan hematokrit sehingga jumlah eritrosit dan/atau kadar hemoglobin yang beredar tidak dapat memenuhi fungsinya untuk menyediakan oksigen bagi jaringan tubuh. Biasanya anemia ditandai dengan penurunan kadar hemoglobin kurang dari $13,5 \mathrm{~g} / \mathrm{dL}$ pada pria dewasa dan kurang dari $11,5 \mathrm{~g} / \mathrm{dL}$ pada wanita dewasa. ${ }^{4}$ Penyebab terjadinya anemia, yaitu: asupan yang tidak adekuat, hilangnya sel darah merah yang di sebabkan oleh trauma, infeksi, perdarahan kronis, menstruasi, dan penurunan atau kelainan pembentukan sel, seperti: hemoglobinopati, talasemia, sferositosis herediter, dan defisiensi glukosa 6 fosfat dihidrogenase. ${ }^{5}$

Besi (Fe) merupakan zat gizi mikro yang sangat diperlukan tubuh. Umumnya zat besi yang berasal dari sumber pangan nabati (non heme), seperti: kacangkacangan dan sayur-sayuran mempunyai proporsi absorbsi yang rendah dibandingkan dengan zat besi yang berasal dari sumber pangan hewani (heme), seperti: daging, telur, dan ikan. ${ }^{6}$ Menurut World Health Organization (WHO), kekurangan zat besi sebagai salah satu dari sepuluh masalah kesehatan yang paling serius. ${ }^{7}$

Remaja adalah salah satu kelompok yang rentan terhadap defisiensi zat besi dan dapat mengenai semua kelompok status ekonomi, terutama yang bersosial ekonomi rendah. $^{8}$ Menurut Riset Kesehatan Dasar (Riskesdas) yang dilakukan pada tahun 2013 didapatkan bahwa prevalensi anemia defisiensi zat besi pada remaja menurut jenis kelamin, yaitu: pada anak perempuan sekitar $22,7 \%$ dan pada anak laki-laki $12,4 \%$ sedangkan menurut tempat tinggal, yaitu: perdesaan $18,5 \%$ dan perkotaan $17,3 \%{ }^{9}$

Penelitian yang dilakukan oleh Manampiring Survei di empat Provinsi (Sumatera Barat, Riau, Bengkulu, dan Lampung) ditemukan bahwa anak usia sekolah termasuk remaja yang menderita anemia sebanyak 45,31\%. ${ }^{10}$ Menurut Dinas Kesehatan Provinsi Sumatera Barat tahun 2014 terdapat 1.833 murid SMP dan 1.718 murid SMA yang menderita anemia. Data ini di ambil dari penjaringan beberapa kota di Provinsi Sumatera Barat. ${ }^{11}$ Menurut Riset
Kesehatan Dasar (Riskesdas) tahun 2013 penduduk Provinsi Sumatera Barat umur $>10$ tahun kurang makan sayur dan buah dengan proporsi sebesar $97,5 \%{ }^{9}$

SMP Negeri 27 terletak di daerah urban. Berdasarkan data murid tahun 2014, didapatkan bahwa sebanyak $80 \%$ para muridnya berasal dari kalangan ekonomi rendah yang sebagian besar pekerjaan orang tuanya adalah buruh dan petani. Dari hasil survei awal yang dilakukan dengan teknik wawancara terdapat 15 dari 20 responden yang tidak teratur dalam mengonsumsi zat besi mereka lebih memilih makanan ringan dibandingkan sayuran dan lauk pauk.

\section{METODE}

Jenis penelitian ini analitik observasional dengan desain cross sectional yang dilaksanakan pada Februari - Juli 2015. Penelitian ini dilaksanakan di SMP Negeri 27 Padang. Pengambilan sampel dengan menggunakan teknik systematic random sampling dengan jumlah populasi 468 murid, sedangkan jumlah sampel penelitian adalah 102 murid SMP Negeri 27 Padang yang memenuhi kriteria inklusi. Data yang dikumpulkan dalam bentuk data primer dan data sekunder. Data primer diperoleh secara langsung oleh peneliti dari responden yang dikumpulkan mengenai identitas dan karakteristik anak. Konsumsi zat besi diukur dengan kuisioner food recall $2 \times 24$ jam dan penetapan kadar hemoglobin dengan metode hemometer digital. Data yang terkumpul selanjutnya dianalisis dengan analisis univariat untuk memberikan gambaran karakteristik masing-masing variabel yang diteliti dan analisis bivariat untuk membuktikan ada atau tidaknya hubungan antara variabel independen dan dependen dengan menggunakan aplikasi komputer dengan uji korelasi Pearson.

\section{HASIL}

Berdasarkan hasil penelitian tentang hubungan kebiasaan mencuci tangan dan memotong kuku dengan kejadian giardiasis didapatkan hasil sebagai berikut. 
Tabel 1. Distribusi frekuensi responden berdasarkan konsumsi zat besi resonden

\begin{tabular}{lcccc}
\hline Kelompok & Rerata & +SD & Min & Max \\
\hline $\begin{array}{l}\text { Zat Besi } \\
\text { (mg/hari) }\end{array}$ & 5,7 & 2,32 & 1,7 & 14,4 \\
\hline
\end{tabular}

Berdasarkan Tabel 1, dapat dilihat bahwa ratarata konsumsi zat besi pada responden sebesar 5,7 $\mathrm{mg} /$ hari dengan konsumsi zat besi terendah sebesar $1,7 \mathrm{mg} /$ hari dan tertinggi sebesar $14,4 \mathrm{mg} /$ hari.

Tabel 2. Distribusi frekuensi responden berdasarkan kadar hemoglobin

\begin{tabular}{lllll}
\hline \multicolumn{1}{c}{ Kelompok } & Rerata & 土SD & Min & Max \\
\hline $\begin{array}{l}\text { Kadar Hemoglobin } \\
(\mathrm{g} / \mathrm{dL})\end{array}$ & 10,1 & 1,23 & 7,3 & 13,6 \\
\hline
\end{tabular}

Berdasarkan Tabel 2, dapat dilihat bahwa ratarata kadar hemoglobin pada responden sebesar 10,1 $\mathrm{g} / \mathrm{dL}$. Kadar hemoglobin terendah adalah 7,3 g/dL, sedangkan yang tertinggi adalah $13,6 \mathrm{~g} / \mathrm{dL}$.

Tabel 3. Distribusi frekuensi anemia berdasarkan kadar hemoglobin

\begin{tabular}{ccc}
\hline $\begin{array}{c}\text { Kadar } \\
\text { Hemoglobin }\end{array}$ & $\mathbf{f}$ & $\%$ \\
\hline$<12 \mathrm{~g} / \mathrm{dL}$ & 96 & 94,1 \\
$\geq 12 \mathrm{~g} / \mathrm{dL}$ & 6 & 5,9 \\
\hline Total & 102 & 100 \\
\hline
\end{tabular}

Berdasarkan Tabel 3, dapat dilihat bahwa responden yang mengalami anemia sebanyak 96 responden $(94,1 \%)$, sedangkan responden yang tidak mengalami anemia sebanyak 6 responden $(5,9 \%)$.

Tabel 4. Distribusi frekuensi anemia berdasarkan kadar jenis kelamin

\begin{tabular}{lcccc}
\hline \multirow{2}{*}{$\begin{array}{l}\text { Jenis } \\
\text { Kelamin }\end{array}$} & \multicolumn{2}{c}{ Anemia } & \multicolumn{2}{c}{ Tidak Anemia } \\
\cline { 2 - 5 } & $\mathbf{f}$ & $\mathbf{\%}$ & $\mathbf{f}$ & $\%$ \\
\hline Perempuan & 69 & 67,6 & 4 & 3,9 \\
\hline Laki-laki & 27 & 26,5 & 2 & 2,0 \\
\hline
\end{tabular}

Berdasarkan Tabel 4, didapatkan bahwa responden perempuan yang anemia sebanyak 69 orang dan yang tidak anemia 4 orang. Sedangkan responden laki-laki yang anemia sebanyak 27 orang dan yang tidak anemia sebanyak 2 orang.
Tabel 5. Korelasi konsumsi zat besi dengan kejadian anemia

\begin{tabular}{cccc}
\hline Konsumsi & Kejadian & $r$ & $p$ \\
\cline { 3 - 4 } Zat Besi & Anemia & 0,099 & 0,323 \\
\hline
\end{tabular}

Berdasarkan Tabel 5, dapat dilihat bahwa hubungan konsumsi zat besi dengan kejadian anemia menunjukan kekuatan hubungan yang sangat lemah $(r=0,099)$ dan berpola positif, artinya semakin tinggi konsumsi zat besi semakin tinggi kadar hemoglobinnya. Hasil uji statistik menunjukan $p>0,05$ artinya tidak ada hubungan yang bermakna antara konsumsi zat besi dengan kadar hemoglobin $(p=0,323)$.

\section{PEMBAHASAN}

Anemia merupakan penurunan kadar hemoglobin di bawah normal akibat dari gangguan metabolisme zat besi yang terdiri dari penyerapan, pengangkutan, penyimpanan, pemanfaatan dan pengeluaran. Hemoglobin merupakan parameter yang sering digunakan untuk menentukan kejadian anemia. Kadar hemoglobin seseorang yang diperoleh dari hasil pengukukuran dengan metode tertentu dan seesuai dengan standar yang telah ditetapkan. ${ }^{12}$

Berdasarkan hasil penelitian pada Tabel 1, didapatkan bahwa rata-rata konsumsi zat besi pada responden sebesar 5,7 mg/hari. Hal ini menunjukan bahwa rata-rata konsumsi zat besi pada murid SMP Negeri 27 Padang dibawah angka kecukupan gizi (AKG). Normalnya anak yang berusia 13-15 tahun mengonsumsi zat besi sebesar 19-26 mg/hari. Hal ini terjadi karena anak-anak tersebut kurang beragam mengonsumsi makanan sehari-hari, terutama sumber protein dan zat besi yang berasal dari makanan hewani, kacang-kacangan, sayur-sayuran dan buahbuahan. Anak-anak tersebut lebih banyak mengonsumsi makanan ringan dan mie instan yang rendah zat besi, sehingga AKG dari zat besi dibawah angka normal.

Berdasarkan hasil penelitian pada Tabel 2, didapatkan bawa rata-rata kadar hemoglobin pada responden sebesar 10,1 $\mathrm{g} / \mathrm{dL}$. Pada tebel 3, didapatkan bahwa presentase anemia lebih banyak dibandingkan yang tidak anemia, yaitu sebesar $94,1 \%$. Hal ini sesuai dengan penelitian yang dilakukan oleh 
Syatriani dan Aryani pada tahun 2010 bahwa 75\% responden mengalami anemia. ${ }^{13}$

Berdasarkan hasil uji korelasi didapatkan bahwa nilai $r=0,099$ menunjukan kekuatan hubungan yang sangat lemah dan berpola positif artinya semakin meningkat konsumsi zat besi semakin meningkat kadar hemoglobinnnya. Hasil uji statistik menunjukan $p=0,323$ yaitu $p>0,05$. Dapat disimpulkan bahwa tidak ada hubungan yang bermakna antara konsumsi zat besi dengan kejadian anemia pada murid SMP Negeri 27 Padang.

Secara teori terdapat terdapat 2 faktor yang menyebabkan terjadinya anemia, yaitu: faktor langsung dan faktor tidak langsung. ${ }^{14}$ Faktor langsung yang dapat menyebabkan anemia, yaitu: adanya infeksi yang disebakan oleh cacing tambang, malaria dan tuberculosis. Menurut penelitian Permaesih dan Herman yang dilakukan pada tahun 2005 hanya 0,8\% anemia yang disebabkan karena infeksi tersebut. ${ }^{15}$ Kemudian, kebutuhan zat besi yang meningkat. Anak dalam masa pertumbuhan memerlukan besi sebanyak 0,5-1 $\mathrm{mg} /$ hari. Seorang gadis remaja memerlukan besi untuk memenuhi kehilangan zat besi akibat menstruasi serta kebutuhan untuk meningkatkan hemoglobin dan masa jaringan dalam kaitannya dengan pertumbuhan.

Asupan serapan zat besi yang tidak adekuat juga dapat menyebabkan anemia, seperti mengonsumsi makanan yang memiliki kualitas besi yang tidak baik (makanan tinggi serat, rendah vitamin $C$, rendah daging), mengonsumsi makanan yang dapat mengangganggu penyerapan zat besi seperti meminum teh dan kopi dan mengonsumsi makanan sampah (junk food) yang hanya sedikit bahkan ada yang tidak ada sama sekali mengandung kalsium, besi, riboflavin, asam folat, vitamin A, dan Vitamin C, sementara kandungan lemak jenuh, kolestrol, dan natrium tinggi. Proporsi lemak sebagai penyedia kalori lebih dari $50 \%$ total kalori yang terkandung dalam makanan itu. ${ }^{2}$

Sedangkan faktor tidak langsung yang memyebabkan terjadinya anemia adalah keadaan sosial ekonomi yang rendah. Pada penelitian diatas didapatkan bahwa sebanyak $80 \%$ muridnya berasal dari kalangan ekonomi rendah dengan sebagian besar pekerjaan orang tuanya adalah buruh dan petani.
Jenis pekerjaan akan dapat menentukan tingkat pendapatan. Tingkat pendapatan juga menentukan pangan yang dibeli. Semakin tinggi pendapat semakin tinggi presentase perbelanjaan yang dibeli termasuk jenis-jenis bahan makanan seperti danging, sayur, dan buah-buahan. Pendapatan keluarga yang memadai akan menunjang tumbuh kembang anak karena orang tua dapat memenuhi kebutuhan anak tersebut.

Selain sosial ekonomi, tingkat pendidikan dan pengetahuan gizi ibu juga merupakan salah satu faktor yang dapat menyebabkan terjadinya anemia. Tingkat pendidikan dan pengetahuan gizi ibu sangat berpengaruh terhadap penyusunan pola makan keluarga dan kualitas zat-zat yang di konsumsi. Semakin tinggi pengetahuan ibu semakin positif sikap ibu terhadap gizi makanan sehingga makin baik pula konsumsi energi, protein, dan besi keluarganya.

Selama penelitian dilaksanakan, sebagian besar murid-murid SMP Negeri 27 Padang berusia 1215 tahun. Anak-anak tersebut tidak sering makan pada malam hari di karenakan ibu mereka yang membatasi makan mereka karena takut berat badan anaknya meningkat. Hal ini terjadi karena kurangnya pengetahuan pada ibu tersebut. Sebenarnya, obesitas terjadi akibat ketidakseimbangan antara asupan dan keluaran energi sehingga mengakibatkan pertambahan berat badan. Anak usia 12-15 tahun mengalami pertumbuhan yang cepat dan aktivitas fisik mereka meningkat sehingga memerlukan asupan energi, protein, dan mineral yang lebih untuk mencukupi kebutuhan tubuh.

Hasil penelitian yang menyatakan tidak ada hubungan konsumsi zat besi dengan kejadian anemia pada murid SMP Negeri 27 padang ini sejalan dengan hasil penelitian yang dilakukan oleh Gunatmaningsih pada tahun 2007 bahwa tidak ada hubungan antara tingkat konsumsi zat besi dengan kejadian anemia. ${ }^{16}$

Beberapa kekurangan masih terdapat dalam penelitian ini, yaitu: penilaian zat besi menggunakan kuisioner food recall 24 jam. Penilaian zat besi dengan cara mewawancarai respoden dapat dipengaruhi oleh keahlian dan pengalaman pewawancara serta daya ingat responden. Responden harus mengingat apa yang dimakan selama 24 jam terakhir. Responden juga sangat sulit menentukan ukuran porsi yang sebenarnya mereka makan. ${ }^{17}$ 
kelemahan dari metode food recall adalah metode ini hanya menilai makanan yang dikonsumsi pada periode 24 jam yang lalu, sedangkan proses terbentuknya anemia berlangsung secara kronis, sehingga metode food recall tidak dapat menggambarkan kejadian anemia.

\section{SIMPULAN}

Didapatkan Kekuatan hubungan yang sangat lemah. Berpola positif, artinya semakin tinggi konsumsi zat besi semakin tinggi kadar hemoglobinnya. Tidak terdapat hubungan yang bermakna antara konsumsi zat besi dengan kejadian anemia pada murid SMP Negeri 27 Padang.

\section{DAFTAR PUSTAKA}

1. Alwi I, Sudoyo AW, Setiyohadi B. Buku ajar ilmu penyakit dalam jilid II. Edisi ke-6. Jakarta: EGC; 2014. hlm.2589-99.

2. Arisman. Gizi dalam daur kehidupan. Jakarta: EGC; 2010.hlm.172-83.

3. Departemen Kesehatan. Menkes Buka Konas Persagi dan Temu IImiah International Persatuan Ahli Gizi Indonesia Tahun 2014. (diunduh 7 Desember 2014). Tersedia dari: URL: HYPERLINK http://www.depkes.go.id/article/view/14120300002/ menkes-buka-konas-persagi-dan-temu-ilmiahinternasional-persatuan-ahli-gizi-indonesia-tahun2014.html.

4. Hoffbrand AV. Kapita selekta hematologi (terjemahan). Edisi ke-6. Jakarta: EGC; 2013. hIm.20-45.

5. Sylvia AP, Lorraine MW. Patofisiology (terjemahan). Edisi ke-6. Jakarta: EGC; 2005.hlm. 256-61.

6. Bakta IM. Hematologi klinik ringkas. Jakarta: EGC; 2006. hlm. 11-38.

7. World Health Organization (WHO). Micronutrient Deficiency. USA: World Health Organization; 2013.hlm. 1-2.
8. Soetjiningsih. Tumbuh kembang remaja dan permasalahannya. Jakarta: EGC; 2004.

9. Badan Penelitian dan Pengembangan Kesehatan Kementrian Kesehatan RI. Riset kesehatan dasar (Riskesdas); 2013.hlm. 179-295

10. Manampiring AE. Prevalensi anemia dan tingkat kecukupan zat besi pada anak sekolah dasar di desa Minaesa Kecamatan Wori Kabupaten Minahasa Utara. E-journal Keperawatan. 2013; 2(1):1-7.

11. Dinas Kesehatan Provinsi Sumatera Barat. Laporan penjaringan anak sekolah program pelayanan kesehatan sekolah Provinsi Sumatera Barat. Padang: tidak di publikasikan; 2014. hlm.2.

12. Nurnia, Hadju V, Kesumasari C. Hubungan pola konsumsi dengan status hemoglobin anak sekolah dasar di wilayah pesisir Kota Makassar. Makassar: Universitas Hasanudin; 2013.hlm.5-6.

13. Syatriani S, Aryani A. Konsumsi makanan dan kejadian anemia pada siswi salah satu SMP di Makassar. Makassar: Jurnal Kesehatan Masyarakat Nasional. 2010;4(6):3-7.

14. Hasanah U. Hubungan asupan tablet besi dan asupan makanan dengan kejadian anemia pada kehamilan di Puskesmas Mojotengah Kabupaten Wonosobo tahun 2012. Jakarta: Universitas Indonesia; 2012.hlm.8-10.

15. Permaesih D, Herman S. Faktor-faktor yang mempengaruhi anemia pada remaja. Jakarta: Buletin Penelitian Kesehatan. 2005;33(4):162-71.

16. Gunatmaningsih D. Faktor-faktor yang berhubungan dengan kejadian anemia pada remaja putri di SMA Negeri 1 Kecamatan Jatibarang Kabupaten Brebes tahun 2007. Semarang: Fakultas Kesehatan Masyarakat Universitas Semarang; 2007.hlm.71.

17. Moris JC. Dietitan's guide to assessment and documentation. Burlington: Jones and Barlett Learning; 2013.hlm.66-7. 